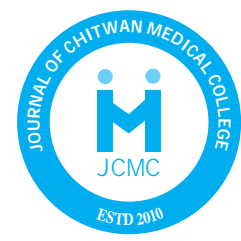

Journal of Chitwan Medical College 2018; (23):36-42

Available online at: www.jcmc.cmc.edu.np

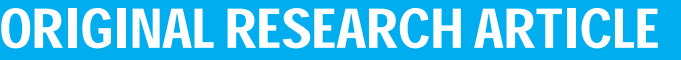

\title{
KNOWLEDGE, ATTITUDE AND PRACTICE REGARDING TOILET TRAINING AMONG MOTHERS OF TODDLER AT KALIKA MUNICIPALITY, CHITWAN \\ Pabitra Sharma, ${ }^{1 *}$ Ganga Gurung, ${ }^{2}$ Shanti Regmi ${ }^{3}$
}

${ }^{1}$ Lecture Sann Institute of Nursing Kathmandu, Nepal

${ }^{2}$ School of Nursing, Chitwan Medical College, Bharatpur, Chitwan, Nepal

${ }^{3}$ Department of Pediatrics, Chitwan Medical College, Bharatpur, Chitwan, Nepal

*Correspondence to: Ms Pabitra Sharma, Lecturer Sann Institute of Nursing, Kathmandu, Nepal.

Email: Pabitrasharma9@gmail.com.

\begin{abstract}
Toilet training is the process of teaching toddler to control bowel and bladder. Mother acts as key role in training process. Therefore, the main objective of the study was to find out awareness, attitude and practice regarding toilet training among mothers of toddler. A descriptive cross-sectional study was conducted in $\mathbf{1 5 5}$ mothers of toddler aged between 15 - 36 months from four wards of Kalika Municipality, selected by using probability, simple random sampling technique. Semi-structured interview was used to find awareness, five points Likert scale for attitude and Interview checklist for practice regarding toilet training. Data were collected date from 24th Oct to 22nd Nov, 2016 and entered in EPI 3.1 and IBM SPSS version 20 and was analyzed using descriptive and inferential statistics. The association between two variables was measured by chi-square test. Study revealed that, $48.4 \%$ had adequate awareness, $49.70 \%$ had satisfactory attitude and $38.1 \%$ had satisfactory level of practice on toilet training. Significant association was found awareness and ethnic group ( $p=0.045)$, education status $(p=0.004)$, education level $(p=0.044)$, occupation $(p=0.008)$, marital status $(p=0.001)$, husbands education $(p=0.010)$ types of family $(p=0.008)$, types of toilet $(p=0.002)$ and birth order $(p=0.026)$. Level of attitude was associated with marital status $(p=0.004)$ while level of practice was associated with economic status $(p=0.024)$, number of children $(p=0.043)$ and age of toddler $(p=0.028)$. It is concluded that less than half of the respondents' have adequate level of awareness and satisfactory level of attitude. But more than one fourth and less than two fourth respondents have satisfactory level of practice regarding toilet training.
\end{abstract}

Key words: Awareness, Attitude, Practice, Toilet Training, Toddler

\section{INTRODUCTION}

Toilet training is a process, where toddlers are taught to teach about controlling of bowel and bladder. It is the first step to make children become self-sufficient. Learning toilet training is based in mainly two ways; teaching by their parents and the child themselves recognizing their body signals and individual ability to control bowel and bladder sphincters. ${ }^{1}$ Toilet training involves the mastery of bowel and urinary control while child is awake and asleep. ${ }^{1}$

Toilet training is expected to be started and achieved during toddlerhood. It is extremely important period for developmental achievement and intellectual growth. ${ }^{2}$

Toilet readiness is a combination of both parents and children willingness to participate for training. Toddlers must be physically and behaviorally responsive for this. By showing some degree of bladder and bowel control is clue for readiness of toilet training. In addition, the parents must be willing for toilet training and be aware of training obstacles, such as the child attending daycare or any physical or mental disabilities the child may have. ${ }^{2}$

Children are expected to grow and learn to theirfullest potential. It is also affected by child's maturation level and intellectual capacity, cultural attitude and the psychological makeup of each parent child level. Parents serve as advocates for children in order to meet needs of all children for access to education and health care process. ${ }^{3}$ Mothers who start toilet training regardless of the toddler readiness may set 
themselves up for lots of frustration for themselves and for their children. ${ }^{4}$

Only $50 \%$ of children wearing nappies for up to a year, completes daytime toilet training by the age of three. $^{5}$

It was also found that improper age of toilet training might influences developing some problems such as constipation, toilet refusal, voiding problems, urinary tract infection and problems like enuresis and uncorrected toilet training could be causative factor for bladder and bowel disorders, which in turn cause problems to both children and their family. ${ }^{6}$

\section{METARIALS AND METHODS}

A descriptive cross-sectional study design was used for the study. A total of 155 mothers of toddler aged between 15- 36 month were selected from four wards of Kalika Municipality by using probability, simple random sampling technique. Semi-structured interview out schedule used to find awareness, five points Likert scale for attitude and Interview checklist for practice regarding toilet training. Data were collected date from 24th Oct to 22nd Nov, 2016 and entered in EPI 3.1 and IBM SPSS version 20 and analysis was done by using descriptive and inferential statistic.

\section{RESULTS}

TABLE 1: Socio-demographic Characteristics of Respondents' $n=155$

\begin{tabular}{|c|c|c|}
\hline Variables & Number & Percentage \\
\hline \multicolumn{3}{|l|}{ Age (in years } \\
\hline$\leq 20$ & 29 & 18.7 \\
\hline$>20$ & 126 & 81.3 \\
\hline \multicolumn{3}{|c|}{ Mean $\pm \mathrm{SD}=25.57 \pm 4.63$, min- $18, \max -36$} \\
\hline \multicolumn{3}{|l|}{ Religion } \\
\hline Hindu & 94 & 60.6 \\
\hline Buddhist & 45 & 29.0 \\
\hline Christian & 16 & 10.4 \\
\hline \multicolumn{3}{|l|}{ Ethnic group } \\
\hline Dalit $^{\circ}$ & 42 & 27.1 \\
\hline Disadvantaged janajaties $^{\text {oo }}$ & 61 & 39.4 \\
\hline $\begin{array}{l}\text { Relatively advantaged } \\
\text { janajaties }^{\text {ooo }}\end{array}$ & 20 & 12.9 \\
\hline Ungrouped caste ${ }^{\circ o o o}$ & 32 & 20.6 \\
\hline
\end{tabular}

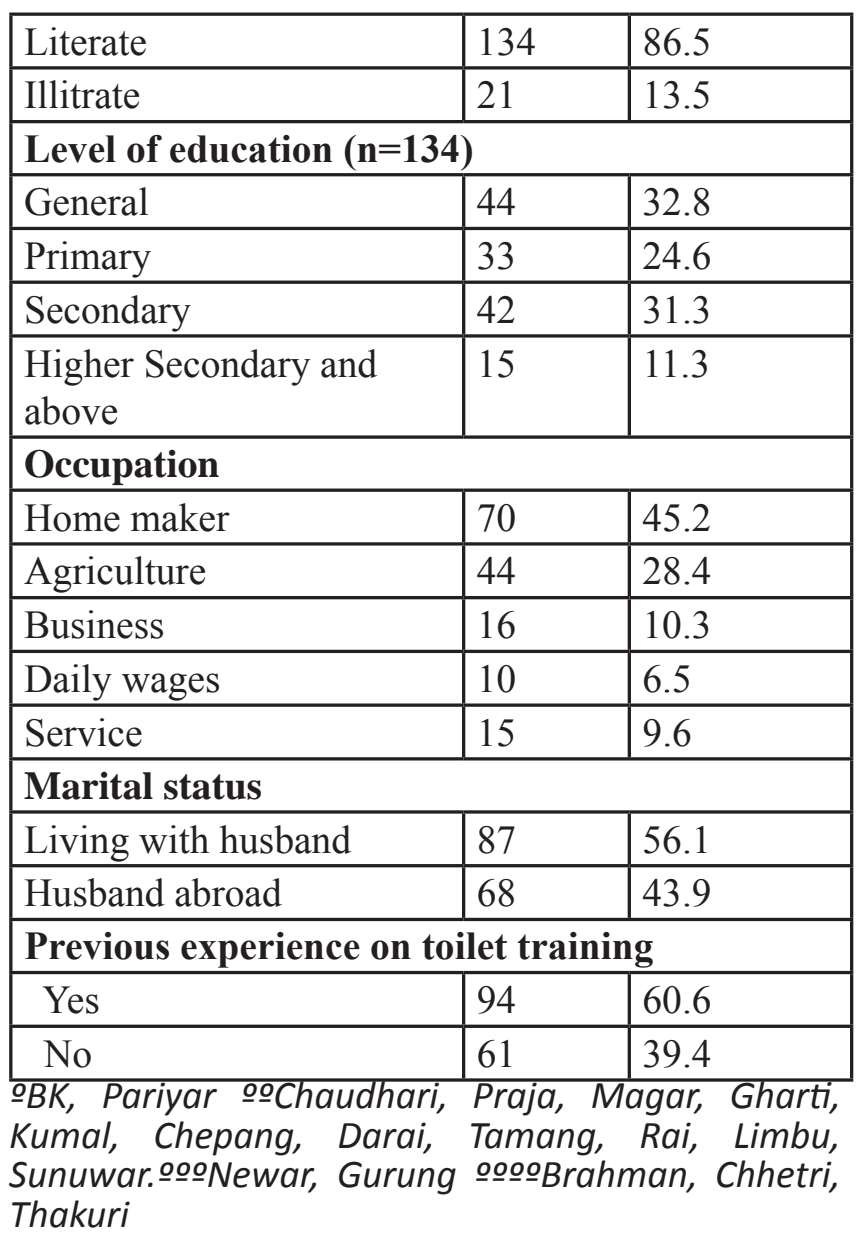

Table 1 shows, out of 155 respondents, 81.3\% respondents were aged above 20 years and $18.7 \%$ were mothers aged equal and below twenty years. Mean age of the respondents was 25.57 years with 4.63 SD.

Regarding religion of the respondents, $60.6 \%$ were Hindus, where as $10.4 \%$ were Christian. Disadvantaged janajaties caste group respondents were $39.4 \%$ followed by relatively advantaged janajaties were $12.9 \%$. While $86.5 \%$ were literate and among literates, $32.8 \%$ had studied general level of education followed by $11.3 \%$ respondents studied up to higher secondary and above level of education. Similarly, $45.2 \%$ were homemaker. Regarding marital status $100 \%$ respondents were married which was not shown in table and among all married respondents, $56.1 \%$ were living with their husband and others were abroad for job. Regarding previous experience, $60.6 \%$ respondents had previous experience on toilet training. 
TABLE 2: Respondents' Family and Toddlers Characteristics $\mathrm{n}=155$

\begin{tabular}{|c|c|c|}
\hline Variables & Number & Percentage \\
\hline \multicolumn{3}{|c|}{ Education status (Husband) } \\
\hline Literate & 143 & 92.3 \\
\hline Illitrate & 12 & 7.7 \\
\hline \multicolumn{3}{|c|}{ Level of education (Husband) $(n=143)$} \\
\hline General & 32 & 22.4 \\
\hline Primary & 32 & 22.4 \\
\hline Secondary & 49 & 34.2 \\
\hline $\begin{array}{l}\text { Higher Second ary } \\
\text { and above }\end{array}$ & 30 & 21.0 \\
\hline \multicolumn{3}{|c|}{ Economic status of family } \\
\hline Enough for a year & 61 & 39.4 \\
\hline $\begin{array}{l}\text { Not enough for a } \\
\text { year }\end{array}$ & 76 & 49.0 \\
\hline Extra saving & 18 & 11.6 \\
\hline \multicolumn{3}{|l|}{ Types of family } \\
\hline Joint & 99 & 63.9 \\
\hline Nuclear & 56 & 36.1 \\
\hline \multicolumn{3}{|l|}{ Types of toilet } \\
\hline Water seal & 136 & 87.7 \\
\hline Pit Latrine & 19 & 12.3 \\
\hline \multicolumn{3}{|l|}{ No of children } \\
\hline One & 50 & 32.3 \\
\hline Two & 58 & 37.4 \\
\hline Three & 30 & 19.3 \\
\hline Four and above & 17 & 11.0 \\
\hline \multicolumn{3}{|c|}{ Age of toddler (in month) } \\
\hline$\leq 18$ & 24 & 15.5 \\
\hline $19-24$ & 59 & 38.1 \\
\hline $25-30$ & 37 & 23.9 \\
\hline $31-36$ & 35 & 22.6 \\
\hline \multicolumn{3}{|c|}{ Mean $\pm \mathrm{SD}=25.54 \pm 6.321$} \\
\hline \multicolumn{3}{|l|}{ Sex of toddler } \\
\hline Male & 80 & 51.6 \\
\hline Female & 75 & 48.4 \\
\hline \multicolumn{3}{|l|}{ Birth order } \\
\hline First & 51 & 32.9 \\
\hline Second & 57 & 36.8 \\
\hline Third & 32 & 20.6 \\
\hline Fourth and above & 15 & 9.7 \\
\hline
\end{tabular}

Table 2 shows that husbands of all 155 respondents 92.3\% were literate. Among literate, $34.2 \%$ had studied up to secondary level of education. Regarding economic status of family of respondents' 49.0\% family did not have sufficient income for whole years followed by $11.6 \%$ respondent families had extra saving also. Regarding type of family, $63.9 \%$ were lived in joint family followed by nuclear family $36.1 \%$. Water sealed type of toilet were used by $87.7 \%$, followed by pit latrines, which were used by $12.3 \%$. Concerning number of children $37.4 \%$ respondents had two children followed by $11.0 \%$ who had four or more than four. Similarly, regarding age of toddler, $38.1 \%$ toddlers were aged between $19-24$ month and $15.5 \%$ toddler was aged below 18 months of age. Mean age of toddler was 25.54 months. Likewise, $51.6 \%$ toddlers were male and $38.8 \%$ current toddlers were second child of respondents.

TABLE 3: Respondents' Awareness Mean Score on Different Aspect of Toilet Training

\begin{tabular}{|l|l|l|l|l|}
\hline $\begin{array}{l}\text { Areas of Aware- } \\
\text { ness }\end{array}$ & $\begin{array}{l}\text { Maxi- } \\
\text { mum } \\
\text { Possible } \\
\text { Score }\end{array}$ & $\begin{array}{l}\text { Mean } \\
\text { Score } \\
\mathbf{\pm S D}\end{array}$ & $\begin{array}{l}\text { Mean } \\
\text { Score } \\
\text { \% }\end{array}$ & Range \\
\hline $\begin{array}{l}\text { General compo- } \\
\text { nents }\end{array}$ & 4 & $2.90 \pm 0.67$ & 72.50 & $2-4$ \\
\hline Toddler readiness & 13 & $5.92 \pm 2.64$ & 45.53 & $1-12$ \\
\hline $\begin{array}{l}\text { Parental compo- } \\
\text { nents }\end{array}$ & 13 & $6.12 \pm 2.12$ & 47.07 & $2-12$ \\
\hline $\begin{array}{l}\text { Time component, } \\
\text { and Parental ac- } \\
\text { tion }\end{array}$ & 4 & $1.84 \pm 0.89$ & 46.00 & $0-3$ \\
\hline $\begin{array}{l}\text { Effective signs, } \\
\text { Hygiene, Reasons } \\
\text { for withholding }\end{array}$ & 13 & $5.78 \pm 1.79$ & 44.40 & $1-10$ \\
\hline $\begin{array}{l}\text { Effects Reasons } \\
\text { of accidental wet- } \\
\text { ting }\end{array}$ & 8 & $5.78 \pm 1.79$ & 44.40 & $1-10$ \\
\hline $\begin{array}{l}\text { Action needed for } \\
\text { toddler negative } \\
\text { reaction. }\end{array}$ & 2 & $0.36 \pm 0.50$ & 18 & 0.2 \\
\hline Total & $\mathbf{5 7}$ & $\mathbf{2 5 . 4 7 \pm 6 . 2}$ & $\mathbf{4 3 . 9 1}$ & $\mathbf{6 - 4 8}$ \\
\hline
\end{tabular}

Table 3 shows, respondents' awareness on different aspect of toilet training. Overall mean score regarding toilet training was $43.91 \%$ where overall mean score regarding general component mean score was $72.50 \%$ with mean $\pm S D, 2.90 \pm 0.67$. It shows that mothers were more aware regarding meaning, age of initiation and age for completion of toilet training. The parental aspect of toilet training mean score was $47.07 \%$ whereas effects of early and

JCMC/ Vol 8/ No. 1/ Issue 23/ Jan-Mar, 2018 
Sharma et al, Journal of Chitwan Medical College 2018; 8(23)

late initiation of toilet training was $33.78 \%$ followed reasons of accidental wetting and action for toddler negative reaction where mean score was $18.0 \%$.

TABLE 4: Respondents' Attitude regarding Toilet Training Statements

$\mathrm{n}=155$

\begin{tabular}{|l|l|l|l|l|l|l|}
\hline Statements & \multicolumn{4}{|c|}{ Responses } \\
\hline Mothers' Aspect & SA & A & UD & DA & SDA & Mean \pm SD \\
\hline Toilet training is job for mother. & 17.4 & 43.9 & 18.1 & 18.7 & 1.9 & $2.43 \pm 1.04$ \\
\hline $\begin{array}{l}\text { Mother /family should also ready for toilet train- } \\
\text { ing. }\end{array}$ & 12.9 & 68.4 & 10.3 & 4.5 & 3.9 & $3.63 \pm 0.99$ \\
\hline $\begin{array}{l}\text { Praise and incentives are important for toilet train- } \\
\text { ing to toddler. }\end{array}$ & 4.5 & 15.5 & 15.5 & 38.1 & 26.5 & $3.48 \pm 0.98$ \\
\hline Toddler needs to punish for regular toilet habits. & 30.3 & 46.5 & 14.2 & 7.1 & 1.9 & $2.02 \pm 0.93$ \\
\hline $\begin{array}{l}\text { Toddler should allow selecting training accesso- } \\
\text { ries. }\end{array}$ & 3.2 & 23.2 & 31.0 & 35.5 & 7.1 & $3.83 \pm 0.99$ \\
\hline $\begin{array}{l}\text { Perineal hygiene and excreta disposal should in- } \\
\text { clude in toilet training. }\end{array}$ & 11.6 & 28.4 & 39.4 & 19.4 & 1.3 & $3.15 \pm 1.03$ \\
\hline It is better to give toilet training in toilets. & 10.3 & 55.5 & 18.1 & 12.3 & 3.9 & $3.29 \pm 1.16$ \\
\hline $\begin{array}{l}\text { Toddler should train everyday whatever the condi- } \\
\text { tion. }\end{array}$ & 9.0 & 33.5 & 18.7 & 34.8 & 3.9 & $2.82 \pm 1.14$ \\
\hline Enough time should be given for toilet training. & 19.4 & 50.3 & 21.3 & 7.1 & 1.9 & $3.60 \pm 1.10$ \\
\hline $\begin{array}{l}\text { Regular and correct toilet training saves money } \\
\text { and time. }\end{array}$ & 4.5 & 35.5 & 36.8 & 21.3 & 1.9 & $2.83 \pm 1.04$ \\
\hline
\end{tabular}

\section{Toddlers' Aspect}

\begin{tabular}{|c|c|c|c|c|c|c|}
\hline Regular toilet training is important for toddler. & 48.4 & 41.9 & 8.4 & 1.3 & 0 & $4.37 \pm 0.69$ \\
\hline $\begin{array}{l}\text { Appropriate age for toilet training is after } 15 \\
\text { months }\end{array}$ & 5.2 & 34.8 & 17.4 & 33.5 & 9.0 & $2.72 \pm 1.18$ \\
\hline $\begin{array}{l}\text { Siblings can increase success rate of toilet train- } \\
\text { ing. }\end{array}$ & 30.3 & 38.7 & 19.4 & 9.7 & 1.9 & $3.78 \pm 1.08$ \\
\hline $\begin{array}{l}\text { Toilet training automatically happens as toddler } \\
\text { grows. }\end{array}$ & 1.9 & 23.9 & 25.2 & 40.6 & 8.4 & $3.16 \pm 1.03$ \\
\hline $\begin{array}{l}\text { Toddlers verbalize for their readiness for toilet } \\
\text { training. }\end{array}$ & 4.5 & 15.5 & 15.5 & 38.1 & 26.5 & $3.38 \pm 1.30$ \\
\hline $\begin{array}{l}\text { Repeated pulling of innerwear is symbol of man- } \\
\text { ner lessnessness. }\end{array}$ & 6.5 & 18.7 & 36.1 & 32.3 & 6.5 & $2.85 \pm 1.05$ \\
\hline Emotional weak toddler usually wets bed. & 11.6 & 47.1 & 25.2 & 14.2 & 1.9 & $2.47 \pm 0.94$ \\
\hline $\begin{array}{l}\text { Use of diapers promotes physical appearance of } \\
\text { toddler. }\end{array}$ & 3.9 & 30.3 & 41.3 & 18.1 & 6.5 & $2.92 \pm 0.94$ \\
\hline $\begin{array}{l}\text { Temper tantrum is also associated with delay toilet } \\
\text { training. }\end{array}$ & 3.2 & 15.5 & 46.5 & 25.8 & 9.0 & $2.81 \pm 0.95$ \\
\hline $\begin{array}{l}\text { Early toilet training means early growth and de- } \\
\text { velopment of toddler }\end{array}$ & 25.2 & 43.9 & 20.0 & 8.4 & 2.6 & $2.16 \pm 0.99$ \\
\hline
\end{tabular}

SA-Strongly agree A-agree UD-Undecided DA-Disagree

SDA-Strongly disagree

Table 4 shows that, out of 155 respondents, 43.9\% respondents were agreed on toilet training is job for mother, mothers readiness for toilet training, 68.4\% respondents were agreed. Concerning praise and incentives $38.1 \%$ respondents were disagreed, $46.5 \%$ respondents were agreed on need of punishment 
for regular toilet training followed by $35.5 \%$ respondents were disagreed on selecting training accessories. Regarding perineal hygiene and excreta disposal in toilet training, 39.4\% respondents were agreed, 55.5\% were agreed on giving toilet training on toilet followed by $34.8 \%$ were disagreed on training daily in spite of toddlers' condition. Similarly $50.3 \%$ respondents were agreed on enough time needed for toilet training and $36.8 \%$ were undecided on saving money and time by toilet training.

Concerning toddler aspect, $48.4 \%$ respondents were agreed on importance of toilet training, $34.8 \%$ were agreed on appropriate age for training followed by $38.7 \%$ agreed on involvement of sibling in toilet training process. Similarly, $40.6 \%$ respondents were disagreed on automatically happening of toilet training as toddlers grow. Verbalization of readiness by toddlers by themselves, 38.1\% were disagreed and $36.1 \%$ respondents were undecided on pulling repeatedly innerwear is symbol of mannerlessness. Concerning accidental wetting $47.1 \%$ were agreed, $41.3 \%$ were undecided on increasing physical appearance by use of diapers. Similarly $46.5 \%$ were undecided on association of temper tantrums with delay toilet training and $43.9 \%$ were agreed on early toilet training means early growth and development.

TABLE 5: Respondents' Practice on Toilet Training

$n=155$

\begin{tabular}{|l|l|l|}
\hline Statements & Number & Percentage \\
\hline Performed toilet training 18-24 month & 35 & 22.6 \\
\hline Trained toddler in morning time & 100 & 64.5 \\
\hline Praised toddler for not wetting innerwear for 2 hours & 56 & 36.1 \\
\hline Took toddler only after he/she verbalized & 48 & 31.0 \\
\hline Took toddlers' siblings help for toilet training & 86 & 55.5 \\
\hline Allowed toddler to select his/her accessories & 55 & 35.5 \\
\hline Make familiar toddler with toilet accessories & 53 & 34.2 \\
\hline Make time schedule for toilet training to your toddler & 41 & 26.5 \\
\hline Spend enough time with toddler while training & 98 & 63.2 \\
\hline Spend minimum 5-10 minute for practice session & 108 & 69.7 \\
\hline Taught to sit in toilets & 66 & 42.6 \\
\hline Allowed toddler to play in potty chair/pots while toileting & 85 & 54.8 \\
\hline Motivate toddler to go toilet regularly & 75 & 48.4 \\
\hline Taught toddler to clean perineal area and hand with soap and water & 53 & 34.2 \\
\hline Used to urinate toddler before sleep & 121 & 78.1 \\
\hline Scold toddler for becoming wet their innerwear & 121 & 78.1 \\
\hline Become angry and show it while training & 61 & 39.4 \\
\hline Performed toilet training every day, whatever the condition of toddler & 34 & 21.9 \\
\hline
\end{tabular}

Table 5 shows, respondents practice regarding toilet training. Only $22.6 \%$ respondents performed toilet training between 18-24 months. Regarding the statement training in morning time, $64.5 \%$ practiced it. For not wetting the innerwear $36.1 \%$ respondents praised their toddler. Likewise $31.0 \%$ respondents took their toddler to toilet only after they verbalized. Respondent who took toddlers siblings help were 55.5\%. And $35.5 \%$ of respondents allowed their toddler to select their training accessories. Respondents who practiced making familiar toddler with accessories were $34.2 \%$. Making regular training schedule, were followed by $26.5 \%$ of respondents. Concerning spending enough time with toddler for training, $63.2 \%$ respondent were practiced it, where, $69.7 \%$ respondents spend minimum 5-10 minute with their toddler in practice session. Similarly $42.6 \%$ respondents used to taught how to sit in toilets and $54.8 \%$ allowed to play while toileting. Respondents who used to motivate their toddler to go toilet were $48.4 \%$. Only $34.2 \%$ respondents used to taught perineal hygiene while toilet training. Regarding practice of urination to toddler before sleep, it was carried out by $78.1 \%$ respondents. Scolding their toddler for becoming wet was done by $78.1 \%$. Likewise respondents who become angry and showed it to toddler and performed toilet training ever day 
Sharma et al, Journal of Chitwan Medical College 2018; 8(23)

in spite of toddlers' condition were $39.4 \%$ and $21.9 \%$ respectively

TABLE 6: Relationship between Awareness, Attitude and Practice Score of Respondents' on Toilet Training

\begin{tabular}{|l|l|c|l|}
\hline \multirow{2}{*}{ Variables } & \multicolumn{3}{|c|}{ Relationship } \\
\cline { 2 - 4 } & Awareness & Attitude & Practice \\
\hline Awareness & 1 & & \\
\hline Attitude & 0.102 & 1 & \\
\hline Practice & $0.277^{*}$ & $0.257^{*}$ & 1 \\
\hline
\end{tabular}

*Significance level at 0.05

Table 6 shows that, Spearman's rank correlation, which was calculated to find out bivariate relationship among respondents awareness, attitude and practice. There was significant relationship found between mothers awareness and practice $(r=0.277 p=<0.001)$ and also significant relationship was found between attitude and practice of mother $(r=0.257 p=<0.001)$. The strength of this relationship was moderate. This indicates that the respondents who had adequate awareness possess satisfactory practice and respondents who had satisfactory attitude possess satisfactory practice regarding toilet training and vice versa.

\section{DISCUSSION}

According to findings of the study, less than half of respondents (48.4\%) had adequate level of awareness. Mean score of awareness was 25.47 \pm 6.20 out of total 57 score with $43.91 \%$ mean percentage. This result is lower than study by Jain (2015) who reported $59.7 \%$. Concerning meaning of toilet training only $40.6 \%$ had awareness. This finding is contrast with study by (Hidayat, 2010) where $81 \%$ had knowledge. In this study $41.3 \%$ had awareness about age for initiation of toilet training. This finding was supported by results of the study by Deneda et al. (2015) who reported $42.1 \%$ had knowledge. Whereas regarding age of completion of toilet training, in this study $2.6 \%$ respondents had awareness.

Regarding practice of toilet training, mean practice of present study was $53.04 \%$ with mean score 9.54 . This finding is almost similar with study by Mallapa et al. (2014) where mean percent was $65.71 \%$ with mean score 11.9 . In current study $22.6 \%$ mother performed toilet training aged after 18-24 month. This finding is lowered in comparison to study by
Denada et al. (2015) where $42.1 \%$ implemented toilet training at age of 18-24 month

In this study, level of awareness in to two categories on basis of median value, in this study $51.6 \%$ had inadequate level of awareness and $48.4 \%$ had adequate level of awareness In comparison, in the study by (Jain, 2015), 28.3\% had inadequate and $71.7 \%$ had moderate level of knowledge and study by Mallapa et al. (2014) revealed that $17 \%$ had adequate, $68 \%$ had moderately adequate, $15 \%$ had inadequate level of knowledge regarding toilet training. Present study revealed, in this study $50.30 \%$ had unsatisfactory level of attitude and $49.70 \%$ had satisfactory level of attitude. In comparison the study by Elgawad and El-khedr, (2014), revealed 97\% had poor level of attitude, and the study by Syari et al. (2015) revealed $35.4 \%$ had positive. $60.8 \%$ had neutral and $3.8 \%$ had negative level of attitude towards toilet training.

This study showed that $61.9 \%$ had unsatisfactory level and $38.1 \%$ had satisfactory level whereas study by Mallapa et al. (2014) 26\% respondents had better practice, $63 \%$ had good and $11 \%$ had poor level of practice. In another similar study by Elgawad and El-khedr, (2014). 5\% had poor practice, $78.33 \%$ had average and $16.66 \%$ had good level of practice regarding toilet training. The current study finding showed that respondents' awareness had statistically significant association with mother educational status $(p=0.004)$, level of education (0.044), occupation ( $p=0.008)$, and types of family $(p=0.008)$. This finding is supported with the result of study by Jain (2015), where $p$ value of these variables was $<0.05$.

In the findings of current study regarding attitude level and respondents' socio-demographic characteristics, there was no significant association between respondents' age $(p=0-66)$, religion $(p=0.80)$, ethnicity $(p=0.37)$, education $(p=0.50)$, husband education $(p=0.32)$, economic status $(p=0.91)$, types of family $(p=0.53)$, number of children $(p=0.70)$, age of toddler $(p=0,52)$, birth order $(p=0.69)$ and past experiences $(p=0.81)$. This finding is supported study by Elgawad and El-khedr, (2014).

Regarding association between level of practice and respondents' socio-demographic characteristics 
and number of children had significant association $(p=0.043)$. This finding is consistent with the study by Mallapa et al. (2014) $(p=<0.05)$. Other variables like age of mother, religion, ethnic group, education level, occupation, marital status husband education, and types of family, types of toilet, sex of toddler and previous experience on toilet training was not significant with level of practice. This finding is consistent with the study by Jain (2015) $(p=>0.05)$. In the present study, there was statistically significant positive $(r=0.277)$ relationship between awareness and practice score of the respondents', which is similar $(r=0.62)$ to the study findings of Mallapa et al. (2014). But there was no relationship between awareness and attitude $(r=0.257)$ of respondents. This is contradictory to the findings $(r=0.53)$ of Elgawad \& El-khedr, (2014). Similarly, present study showed significant positive $(r=0.257)$ relationship between practice score and attitude score, and this finding is similar with the study by Elgawad \& Elkhedr, (2014).

\section{CONCLUSION}

Based on the findings of the study conclusion has been drawn. It is concluded that less than half of the respondents' have adequate level of awareness and satisfactory level of attitude. But more than one fourth and less than two fourth respondents have satisfactory level of practice regarding toilet training. Mothers' awareness level was limited on signs of readiness, time component, possible effects and reasons for wetting and parental action for negative reaction of toddlers. There was significant association between respondents' level of awareness and. educational status and levels of education, occupation, marital status, education status and level of husband, types of family, types of toilet and birth order. Those mothers who were literate, studied higher level of education, engaged in service had more adequate of awareness. Whereas level of attitude was significant with marital status of respondents and economic status, number of children and age of toddler with level of practice. Furthermore, there is correlation between awareness and practice score, practice score and attitude score but, no correlation between awareness and attitude score regarding toilet training among mothers of toddler. Therefore regular counseling programme is needed to enhance mothers' awareness and make their attitude and practice satisfactory regarding toilet training and avoid possible effects associated with early and late, improper toilet training.

\section{REFERENCES}

1. Hussain KA. Mother's knowledge over childtoilet training in Sebardan village in Erbil. Zanco J Medical Science 2011; 16(3).

2. Denada RO, Nazriati E, Chandra.F. Description of knowledge and attitude about mother implementation of toilet training in children. JOurnal Online Mahasiswa 2015; 2(2).

3. Jain A. A Study to assess the knowledge and knowledge of practices regarding toilet training among mothers of preschool children in selected urban community at Udaipur city. International Journal of Nursing Education 2011; 7(2):1-4.

4. Thammajinda OA. The Effectiveness of a parental education intervention about a child-oriented approach to toileting for healthy Thai toddlers. 2013.

5. Christophersen ER, VanScoyoc S. Toilet training and toileting problems: How do we advise parents? AAP Section of Developmental and Behavioral Pediatrics Newsletter. 2008; 17(1): 7-10.

6. Barone JG, Jasutkar N, Schnieder D. Later toilet training is associated with urge incontinence in children. Journal of Pediatric Urology. 2014; 1 e4.

7. Hidayat I.H. Mothers knowledge on toilet training among preschool children of Madan. Med J Bakirkoy. 2011; 7(1).

8. Hooman, Nakysa, Afshin S, Ehsan, V, Zahra A. Toilet training in Iranian children: A crosssectional study. Iran Journal of Pediatrics. 2014; 23 (3): Retrieved from https://www.ncbi.nlm. nih.gov/pmc/ articles/PMC3663305

9. Elgawad A, El-Khedr SM. Saudi mothers' knowledge, attitudes and practices regarding toilet training readiness of their toddlers. Global Journal on Advances Pure and Applied Sciences. 2014; 4: Retrieved on http://www.academia. edu/29972275

10. Elsera C. Attitude knowledge levels associated with women in toilet training on toddler. Journal of Nurses and Midwifery Indonesia. 2014; 4(1): 35-38. doi: http//dx.doi.org/10.21927/ jnki.2016.4(1).35-38 